\title{
Adsorption of Atrazine and Terbacil by Soils
}

\author{
L. C. Liu, H. Cibes-Viadé, and F. K. S. Koo
}

\section{INTRODUCTION}

The adsorption of 2-chloro-4-(ethylamino)-6-(isopropylamino)-s-triazine (Atrazine) and 3-tert.-butyl-5-chloro-6-methyl uracil (Terbacil), by soils has been studied by a number of research workers $(1,2,3,4,5,8,9,10) .{ }^{2}$ Information concerning such adsorption under tropical conditions is wanting. Such information is essential for understanding the behavior of such compounds in the soil. Data was presented in a previous publication (7) concerning the adsorptive capacity of 34 native soils of two of our most currently used herbicides, 2-(ethylamino)-4-(isopropylamino)-6-(methy]thio)-s-triazine (Ametryne) and 3-(3,4-dichlorophenyl)-1,1-dimethylurea (Diuron). Data also was presented concerning the effects of various environmental factors upon the adsorption characteristics of these two herbicides. In the present study, Ametryne and Diuron were substituted by Atrazine and Terbacil. Atrazine is used extensively to control noxious weeds in various crops of economic importance of Puerto Rico including sugarcane (Saccharum officinarum). Terbacil shows promise for control of weeds in sugarcane.

\section{MATERIALS AND METHODS}

Samples from the upper layer $(15 \mathrm{~cm}$.) of 34 soil types were collected from various regions of Puerto Rico representing a wide variety of climatic: and edaphic conditions. The samples were air-dried, ground and passed through a $0.25-\mathrm{mm}$. screen. The physical and chemical properties of these soils were determined by methods similar to those employed previously $(6)$.

To determine the extent to which Atrazine and Terbacil were adsorbed by each soil, the radioassay procedure outlined by Talbert and Fletchall (10) was followed. Stock solutions (concn. 1 p.p.m.) containing either ringlabeled $\mathrm{C}^{14}$-Atrazine (specific activity $10.1 \mu \mathrm{c}$./mg.) or 2-C ${ }^{14}$-Terbacil (spe-

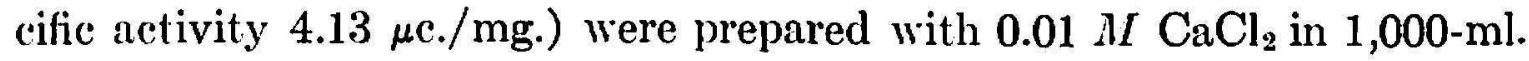

'Associate Plant Physiologist and Plant Physiologist, respectively, Agricultural Experiment Station, Mayagïez Campus, University of Puerto Rico, and Senior Scientist and Head, Agricultural Bioscience Division, Puerto Rico Nuclear Center, Río Piedras, P.R. Appreciation is due Mr. J. Juárez, Jr., Soil Scientist, for his help in the rollection and identification of soil samples from various regions of Puerto Rico. The radionetive samples of Atraiue and Terbaril were generously supplied by (icigy Agricultural (hemicals and F. I. I)uPont de Nemours \& Co., respectively.

2 Italie numbers in pareutheses refer 10 Literature Cited, p. 460. 
volumetric flask. Five ml. of each herbicide were added from stock solutions to Erlenmeyer flasks containing soil samples. The flasks were stoppered and agitated in a reciprocal shaker at room temperature for 24 hours. Individual samples then were transferred to $15-\mathrm{ml}$.-capacity glass tubes and centrifuged for 20 minutes at 5,000 r.p.m. Subsequently, $0.5 \mathrm{ml}$. of the supernatant was removed and placed in a glass-counting vial. Ten $\mathrm{ml}$. of liquid scintillator (0.4 percent 2,5 -diphenyloxazole and 0.01 percent 1,4 bis-2-(5phenyloxazole)-benzene in $1,000 \mathrm{ml}$. of toluene) were added to each vial. Each vial then was placed in a Beckman model automatic liquid scintillation spectrometer for a 5-minute count. Five ml. of blank standards with a series of known concentrations $(0.1,0.2,0.4,0.6,0.8$, and 1.0 p.p.m.) were included in the study and used for plotting the standard curve for each herbicide. The concentration of herbicide remaining in solution for the various soil samples was estimated by fitting the radioactivity measured in the aqueous solution of these samples to that of the standard curve. The difference between the original concentration and residual concentration represents the amount of herbicide adsorbed by the soil. All determinations were made in triplicate.

For making the adsorption isotherms studies, one g. of air-dried soil was placed in an Erlenmeyer flask with $5 \mathrm{ml}$. of stock solution of different initial herbicide concentrations $(0.625,1.25,2.5,5.0$ and 10.0 p.p.m. for Atrazine; $0.3125,0.625,1.25,2.5$ and 5.0 p.p.m. for Terbacil). The same methodology employed in the first phase of the adsorption study was used again. Adsorption isotherms were prepared by plotting the amount of herbicide adsorbed against the herbicide concentration in the equilibrated solution. Each point on the adsorption isotherms represented the average of three determinations except that only duplicate determinations were made with the highest concentration of Atrazine (10 p.p.m.).

\section{RESULTS}

The physical and chemical properties of the 34 soils used in the study are presented in table 1 . The observed and estimated adsorption percentage for Atrazine and Terbacil in 34 soils are presented in table 2. Caño Tiburones soil manifested considerably higher capacity for adsorption of Atrazine and Terbacil than all other soils, whereas, Toa sandy loam showed the lowest adsorptive capacity for Atrazine and Talante sandy loam for Terbacil. Adsorption of Atrazine and Terbacil by other types was between these two extremes. It is significant to note that the adsorption of Atrazine and Terbacil appeared to be relatively low when rompared to that of Ametryne and Diuron (table 3). 'Thus, the relative adsorptivity of these soils for the herbicides is the following: Diuron > Ametryne $>$ Atrazine $>$ Terbacil. Harris (2) and Talbert (10) also reported the low adsorption 
TABLE 1.-The chemical and physical properties of 34 Pucrlo Rican soils

\begin{tabular}{|c|c|c|c|c|c|c|c|c|c|c|}
\hline \multirow{2}{*}{ Soil name } & \multirow{2}{*}{$\underset{\text { p.p.m. }}{\stackrel{P}{\text { P. }}}$} & \multirow{2}{*}{$\mathrm{pH}$} & \multicolumn{4}{|c|}{ Meq. per $100 \mathrm{~g}$. } & \multicolumn{4}{|c|}{ Percent } \\
\hline & & & CEC & $\mathrm{Ca}$ & $\mathrm{Mg}_{\mathbf{g}}$ & $\mathbf{K}$ & OM & Sand & Silt & Clay \\
\hline lilla loamy sand & 17 & 7.4 & 10.0 & 17.1 & 3.3 & 0.20 & 2.5 & 74.4 & 19.5 & 6.1 \\
\hline Aguirre clay loam & 22 & 9.0 & 14.3 & 18.3 & 28.8 & 1.44 & 1.3 & 27.6 & 35.6 & 36.8 \\
\hline Alonso clay & 4 & 5.1 & 13.8 & 5.4 & 2.0 & 0.91 & 3.2 & 14.9 & 39.3 & 45.8 \\
\hline Altura loam & 33 & 8.0 & 27.6 & 32.2 & 7.8 & 1.94 & 3.7 & 49.2 & 28.8 & 22.0 \\
\hline $\begin{array}{l}\text { Bayamón sandy clay } \\
\text { loam }\end{array}$ & 6 & 4.7 & 5.0 & 2.7 & 1.5 & 0.19 & 1.7 & 68.1 & 4.4 & 27.5 \\
\hline Caño Tiburones muck & 6 & 5.5 & 86.0 & 61.9 & 14.0 & 0.80 & 36.0 & 36.0 & 36.0 & 28.0 \\
\hline Catalina clay & 1 & 4.7 & 11.8 & 0.7 & 0.6 & 0.08 & 1.9 & 6.6 & 28.9 & 64.5 \\
\hline ataño sand & 14 & 7.9 & 6.9 & - & 0.2 & 0.15 & 2.1 & 89.0 & 7.3 & 3.7 \\
\hline andy loam & 4 & 5.2 & 7.3 & 32.2 & 7.8 & 1.94 & 2.0 & 58.8 & 23.4 & 17.8 \\
\hline & 5 & 5.4 & 18.6 & 6.9 & 7.0 & 0.54 & 4.9 & 13.3 & 34.8 & 51.9 \\
\hline Jom & 8 & 5.7 & 23.0 & 14.9 & 5.8 & 0.15 & 3.7 & 22.7 & 37.4 & 39.9 \\
\hline & 13 & 7.7 & 14.0 & 16.6 & 0.7 & 0.35 & 3.2 & 23.4 & 24.8 & 51.8 \\
\hline & 13 & 7.5 & 27.6 & 8.7 & 20.8 & 0.81 & 3.4 & 39.1 & 29.7 & 32.2 \\
\hline & $\mathbf{5}$ & 5.4 & 23.3 & 9.2 & 10.1 & 0.15 & 3.3 & 15.0 & 50.7 & 34.3 \\
\hline & 15 & 6.3 & 36.0 & 24.0 & 10.4 & 0.46 & 2.1 & 15.5 & 32.5 & 52.0 \\
\hline $\begin{array}{l}\text { clny (Lajas } \\
\text { n) }\end{array}$ & 33 & 5.9 & 58.0 & 27.6 & 19.0 & 0.65 & 4.2 & 11.1 & 23.8 & 65.1 \\
\hline Guánica clay & 36 & 8.1 & 52.1 & 41.5 & 37.7 & 2.58 & 4.8 & 6.4 & 19.6 & 74.0 \\
\hline $\mathrm{H}_{\mathbf{l}}$ & 4 & 4.5 & 10.1 & 2.2 & 0.9 & 0.27 & 1.7 & 10.1 & 50.9 & 39.0 \\
\hline & 5 & 6.0 & 16.8 & 7.4 & 9.5 & 0.22 & 3.3 & 26.6 & 53.5 & 20.9 \\
\hline & 9 & 6.2 & 13.4 & 16.6 & 28.8 & 0.17 & 2.7 & 15.2 & 41.6 & 43.2 \\
\hline & 16 & 7.0 & 55.2 & 19.1 & 43.7 & 0.50 & 3.9 & 19.9 & 33.4 & 46.7 \\
\hline & 3 & 5.7 & 31.0 & 11.5 & 14.2 & 0.56 & 4.9 & 22.7 & 40.7 & 30.6 \\
\hline & 25 & 8.1 & 19.9 & 49.9 & 9.9 & 1.02 & 2.4 & 14.9 & 42.8 & 42.3 \\
\hline & 6 & 5.8 & 31.0 & 23.4 & 4.7 & 0.22 & 3.8 & 26.3 & 27.7 & 46.0 \\
\hline lo 0 & 6 & 5.8 & 19.6 & 13.6 & 7.8 & 0.14 & 3.3 & 28.0 & 47.0 & 25.0 \\
\hline & 2 & 5.7 & 11.9 & 4.4 & 2.5 & 0.05 & 5.3 & 22.0 & 49.2 & 28.0 \\
\hline & 5 & 5.7 & 7.7 & 5.5 & 2,4 & 0.13 & 2.0 & 59.4 & 28.2 & 12.4 \\
\hline 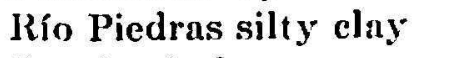 & 4 & 4.9 & 11.5 & 3.9 & 2.0 & 0.08 & 3.5 & 13.4 & 43.6 & 43.0 \\
\hline & 16 & 6.7 & 26.1 & 23.8 & 5.9 & 0.58 & 2.7 & 24.3 & 49.7 & 26.0 \\
\hline Talante sandy loam & 7 & 5.1 & 4.0 & 0.9 & 0.2 & 0.17 & 1.4 & 73.4 & 19.4 & 7.2 \\
\hline & 2 & 5.3 & 13.0 & (i.9) & 1.5 & 0.23 & 2.0 & 41.5 & 38.3 & 20.2 \\
\hline & 8 & (i. 0 & 8.0 & 6.2 & 1.4 & 0.17 & 0.6 & 60.9 & 25.1 & 14.0 \\
\hline Ita saudy loam & 2 & 5.0 & 5.6 & 1.1 & 1.3 & 0.02 & 3.5 & 73.7 & 12.0 & 13.7 \\
\hline Via loam & 3 & 5.1 & 39.9 & 3.9 & 3.5 & 0.10 & 2.3 & 45.2 & 36.8 & 18.0 \\
\hline
\end{tabular}

of Atrazine as contrasted with other herbicides of the s-triazine family. As to Terbacil, Rhode et al. (9) found the adsorption of this herbicide to be only slightly greater than that of 5-bromo-3-sec-butyl-6-methyluracil (Bromaril) but appreciably less than that of other triazine and urea herbicides he investigated. The low adsorptive capacity of soils for Terbacil, 
TAHLE 2.-Observed and estimaled adsorption percentage for Atrazine and Terbacil in 34 Puerto Rican soils

\begin{tabular}{|c|c|c|c|c|c|c|}
\hline \multirow{3}{*}{ Soil name } & \multicolumn{6}{|c|}{ Adsorption percentage } \\
\hline & \multicolumn{3}{|c|}{ Atrazine } & \multicolumn{3}{|c|}{ Terbacil } \\
\hline & $\begin{array}{c}\text { Ob- } \\
\text { served }\end{array}$ & $\begin{array}{c}\text { Esti- } \\
\text { mated }\end{array}$ & $\begin{array}{l}\text { Differ- } \\
\text { ence }\end{array}$ & $\begin{array}{c}\text { Ob- } \\
\text { served }\end{array}$ & $\begin{array}{c}\text { Esti- } \\
\text { mated }\end{array}$ & $\begin{array}{c}\text { Differ- } \\
\text { ence }\end{array}$ \\
\hline Aguadilla loamy sand & 10 & 10 & 0 & 5 & 7 & -2 \\
\hline Aguirre clay loam & 8 & 10 & -2 & 8 & 9 & -1 \\
\hline Alonso clay & 12 & 14 & -2 & 5 & 6 & -1 \\
\hline Altura loam & 11 & 15 & -4 & 8 & 10 & -2 \\
\hline Bayamón sandy clay loam & 7 & 5 & +2 & 3 & 3 & 0 \\
\hline Caño Tiburones muck & 80 & -1 & - & 54 & -1 & - \\
\hline Catalina clay & 7 & 9 & -2 & 4 & 4 & 0 \\
\hline Cataño sand & 10 & 7 & +3 & 4 & 6 & -2 \\
\hline Cayaguá sandy loam & 7 & 9 & -2 & 3 & $\mathbf{5}$ & -2 \\
\hline Cialitos clay & 21 & 20 & -1 & 9 & 10 & -1 \\
\hline Coloso clny loam & 19 & 16 & +3 & 10 & 8 & +2 \\
\hline Coto clay & 14 & 13 & +1 & 8 & 8 & 0 \\
\hline Fe clay loam & 13 & 16 & -3 & 11 & 11 & 0 \\
\hline Fortuna silty clay loam & 20 & 16 & +4 & 10 & 8 & +2 \\
\hline Fraternidad clay & 12 & 11 & +1 & 8 & 6 & +2 \\
\hline Fraternidad clay (Lajas Substation) & 21 & 18 & +3 & 14 & 11 & +3 \\
\hline Guánica clay & 18 & 21 & -3 & 13 & 16 & -3 \\
\hline Humata silty clay loam & 10 & 10 & 0 & 3 & 3 & 0 \\
\hline Josefa silty loam & 17 & 16 & +1 & 9 & 8 & +1 \\
\hline Juncos silty clay & 18 & 15 & +3 & 10 & 9 & +1 \\
\hline Mabí clay & 22 & 20 & +2 & 14 & 14 & 0 \\
\hline Mabi clay loam & 17 & 21 & -4 & 10 & 11 & -1 \\
\hline Mercedita silty clay & 12 & 13 & -1 & 11 & 8 & +3 \\
\hline Moca clay & 19 & 15 & +4 & 10 & 8 & +2 \\
\hline Múcara loam & 14 & 16 & -2 & 8 & 8 & 0 \\
\hline Nipe clay loam & 24 & 22 & +2 & 13 & 11 & +2 \\
\hline Pandura sandy loam & !) & 9 & 0 & 4 & 5 & -1 \\
\hline Río Piedras silty clay & 8 & 15 & -7 & 3 & 7 & -4 \\
\hline San Antón loam & 18 & 14 & +4 & 10 & 7 & +3 \\
\hline Talante sandy loam & (j) & 6 & 0 & 2 & 3 & -1 \\
\hline Toa loam & 9 & 10 & -1 & 4 & 4 & 0 \\
\hline Toa sandy loam & 5 & 4 & +1 & 3 & 2 & 1 \\
\hline Vega Alta sandy loam & 14 & 12 & +2 & 5 & 7 & -2 \\
\hline Via loam & 10 & 11 & -1 & 4 & 5 & -1 \\
\hline
\end{tabular}

1 Jata on Caño Tiburones soil not included in multiple regression analyses.

as noted in this study, is in keeping with the results of Mee ( $\tilde{5})$ who observed the same phenomenon in Hawaiian soils.

Adsorption of Atrazine was correlated positively with organic matter content, cation exchange capacity, (CEC) magnesium content, and percent of silt and clay, but negatively with percent of sand (table 4). In a series 
of multiple regression analyses involving the adsorption percentage and various soil properties, it was found that a combination of organic matter, magnesium and silt offered a basis for the best prediction for adsorption of

T.1BLE 3.-Observed alsorption percenlage for Amelryne and Diuron in 34 Puerto Rican soils

\begin{tabular}{|c|c|c|}
\hline \multirow{2}{*}{ S.jil type } & \multicolumn{2}{|c|}{ Adsorption Percentage ${ }^{1}$} \\
\hline & Ametryne & Diuron \\
\hline Aguadilla loamy sand & 22 & 36 \\
\hline Aguirre clay loam & 20 & 29 \\
\hline Alonso clay & 40 & 35 \\
\hline Altura loam & 18 & 38 \\
\hline Bayamón sandy clay loam & 22 & 22 \\
\hline Caño Tiburones muck & 94 & 98 \\
\hline Catalina clay & 20 & 19 \\
\hline Cataño sand & 15 & 32 \\
\hline Cayaguá sandy loam & 27 & 26 \\
\hline Cinlitos clay & 56 & 58 \\
\hline Coloso clay & 47 & 57 \\
\hline Coto clay & 18 & 51 \\
\hline Fe clay loam & 25 & 40 \\
\hline Fortuna silty clay loam & 64 & 59 \\
\hline Frateruidad clay & 23 & 44 \\
\hline Fraternidad clay (Lajas Substation) & 44 & 63 \\
\hline Guánica clay & 27 & 51 \\
\hline Humata silty clay loam & 30 & 21 \\
\hline Josef a silty loam & 39 & 57 \\
\hline Juncos silty clay & 51 & 52 \\
\hline Mabí clay & 38 & 61 \\
\hline Mabí clay loam & 34 & 53 \\
\hline Mercedita silty clay & 17 & 39 \\
\hline Moca cluy & 57 & 57 \\
\hline Múcara loam & 50 & 42 \\
\hline Nipe clay loam & +8 & 62 \\
\hline Pandura sandy loam & 25 & 36 \\
\hline Río Piedras silty clay & 23 & 30 \\
\hline Sin Antón loam & 29 & 63 \\
\hline Talante sandy loam & 37 & 22 \\
\hline Toa loam & 48 & 30 \\
\hline Ton sandy loam & 15 & 15 \\
\hline Vega Alta sandy loam & 32 & 42 \\
\hline Via loam & 45 & 37 \\
\hline
\end{tabular}

1 The same methodology used for determining the adsorption of Atrazine and Terbacil by the soil was used here.

Atrazine. Consecquently, the multiple regression equation $y=-0.031+$ $0.107(\mathrm{Ig})+3.216$ (organic matter) +0.088 (silt) was used to calculate the estimated adsorption percentage for Atrazine (table 2). 
T.1BLe 4.--Simple correlation of soil properlies among themselves and wilh adsorplion percenlage for Alrazine and Terbacil herbicicies using the experimental data from 39 soil types, exrluding Caño Tiburones soilt

\begin{tabular}{|c|c|c|c|c|c|c|c|c|c|c|c|}
\hline Factors correlated & & $\mathbf{P}$ & pHI & CEC & $\mathrm{Ca}$ & Mg & $\mathbf{K}$ & $\begin{array}{l}\text { Organic } \\
\text { matter }\end{array}$ & Sand & Silt & Clay \\
\hline & & p.p.m. & & Meq. $/ 100 \mathrm{~s}$ & Meq. $/ 100 \mathrm{~g}$ & . Meq./100 g. & S/eq. $/ 100 \mathrm{~g}$ & Percent & Percent & Percent & Percent \\
\hline $\begin{array}{l}\text { Adsorption } \\
\text { Atrazine }\end{array}$ & for & 0.167 & 0.110 & $0.568^{* *}$ & 0.239 & $0.446^{*}$ & -0.020 & $0.810^{* *}$ & $-0.528^{* *}$ & $0.379^{*}$ & $0.427^{*}$ \\
\hline $\begin{array}{c}\text { Adsorption percentage } \\
\text { Terbacil }\end{array}$ & for & $.495^{* *}$ & $.446^{*}$ & $.700^{* *}$ & $.530^{* *}$ & $.666^{* *}$ & .262 & $.720^{* *}$ & $-.558^{* *}$ & .315 & $.513^{* *}$ \\
\hline $\mathrm{P}_{2} \mathrm{O}_{s}$ p.p.m. & & & $.762^{* *}$ & $.560^{* *}$ & $.777^{* *}$ & $.536^{* * *}$ & $.663^{* *}$ & .154 & -.127 & -0.223 & .324 \\
\hline $\mathrm{H}$ & & & & .269 & $.667^{* *}$ & $.492^{* *}$ & $.519^{* *}$ & .057 & .025 & -0.141 & .068 \\
\hline $\mathrm{CEC}$ & & & & & $.489^{* *}$ & $.654^{* *}$ & .342 & $.501^{* *}$ & $-.483^{* *}$ & .102 & $.564^{* *}$ \\
\hline $\mathrm{Ca}$ & & & & & & $.458^{* *}$ & $.708^{* *}$ & .177 & -.243 & -.052 & .338 \\
\hline $\mathrm{Mg}$ & & & & & & & $.490^{* *}$ & .301 & $-.379^{*}$ & .064 & $.455^{* *}$ \\
\hline & & & & & & & & .163 & -.151 & -.132 & .292 \\
\hline Drganic matter (percent) & & & & & & & & & $-.444^{*}$ & .222 & $.428^{*}$ \\
\hline Sand & & & & & & & & & & $.661^{* *}$ & $-0.849^{* *}$ \\
\hline Silt & & & & & & & & & & & .164 \\
\hline
\end{tabular}

$1 *$ Significant at the 5 percent level

** Significant at the 1 percent level 
Adsorption of Terbacil was correlated positively with organic matter, cation exchange capacity, magnesium and calcium content, soil $\mathrm{pH}$, phosphorus content and percent of clay, and again negatively correlated with percent of sand. Similarly, the multiple regression equation $y=-3.20+$ 0.675 (soil $\mathrm{pH})+0.121(\mathrm{Mg})+1.844$ (organic matter) was derived and used to calculate the estimated adsorption percentage for Terbacil.

To better characterize the adsorption behavior of Atrazine and Terbacil on 12 major sugarcane soils, the empirical constants $(K)$ and lines slopes $(1 / n)$ of the Freundlich expression

$$
\log x / m=\log K+1 / n \log C
$$

TABLE 5.-Freundlich isothermal constants at 1.0 p.p.m. soil solution concentration for 12 Puerlo Rican soils ${ }^{1}$

\begin{tabular}{lcccccc}
\hline \multirow{2}{*}{ Soil Name } & \multicolumn{2}{c}{ Atrazine } & & \multicolumn{2}{c}{ Terbacil } \\
\cline { 2 - 3 } \cline { 5 - 6 } & $\mathrm{K}$ & $1 / n$ & & $\mathrm{~K}$ & $1 / n$ \\
\hline Aguirre clay loam & 0.90 & 0.90 & & 0.72 & 0.73 \\
Coloso clay loam & 2.03 & 0.93 & & 0.93 & 0.93 \\
Coto clay & 1.20 & 1.00 & & 0.74 & 0.90 \\
Fortuna silty clay loam & 2.47 & 0.87 & & 0.97 & 0.97 \\
Fraternidad clay & 1.10 & 0.93 & & 0.77 & 1.00 \\
Guánica clay & 1.85 & 0.97 & & 1.50 & 1.00 \\
Juncos silty clay & 2.00 & 0.87 & & 1.12 & 0.97 \\
Mabín clay & 2.80 & 0.93 & & 1.05 & 0.97 \\
Mercedita silty clay. & 1.20 & 0.97 & & 1.13 & 1.00 \\
Moca clay & 2.10 & 0.87 & & 1.32 & 1.11 \\
Nipe clay loam & 2.70 & 0.93 & & 1.40 & 0.90 \\
San Antón loam & 2.05 & 0.93 & & 1.18 & 0.93 \\
\hline
\end{tabular}

1 Values of $K$ in the table are the values of $\mathrm{X} / \mathrm{m}$ in $\mu \mathrm{g} / \mathrm{g}$ at an arbitrary solution concentration of 1 p.p.m.

Values of $1 / n$ are the values of the slopes of the plots of $\log X / m$ against $\log C$.

are extrapolated graphically from the adsorption isotherms and given in table 5. Our experimental data generally was found to fit the linearity relationship as shown by the representative adsorption isotherms (figs. 1 and 2). Deviations from linearity were noted with some soils at the lowest concentration for both Atrazine and Terbacil. Hilton and Yuen (4) also found a similar type of deviation, especially at the lower Atrazine concentration ranges. As can be seen in table 5, Mabi clay was found to have the highest $K$ values for Atrazine and Terbacil. On the other hand, Aguirre clay has the lowest $K$ values for both herbicides. These various $K$ values, together with their corresponding line slopes, are generally sufficient to characterize the adsorption relationship of Atrazine and Terbacil on a number of our soils. The advantage of using the isothermal adsorption 
method is that the results obtained are not influenced by soil-herbicidesolution ratios.

\section{SUMMARY}

The differential in the adsorption capacity of 2-chloro-4-(ethylamino)-6(isopropylamino)-s-triazine (Atrazine) and 3-tert.-butyl-5-chloro-6-methyl-

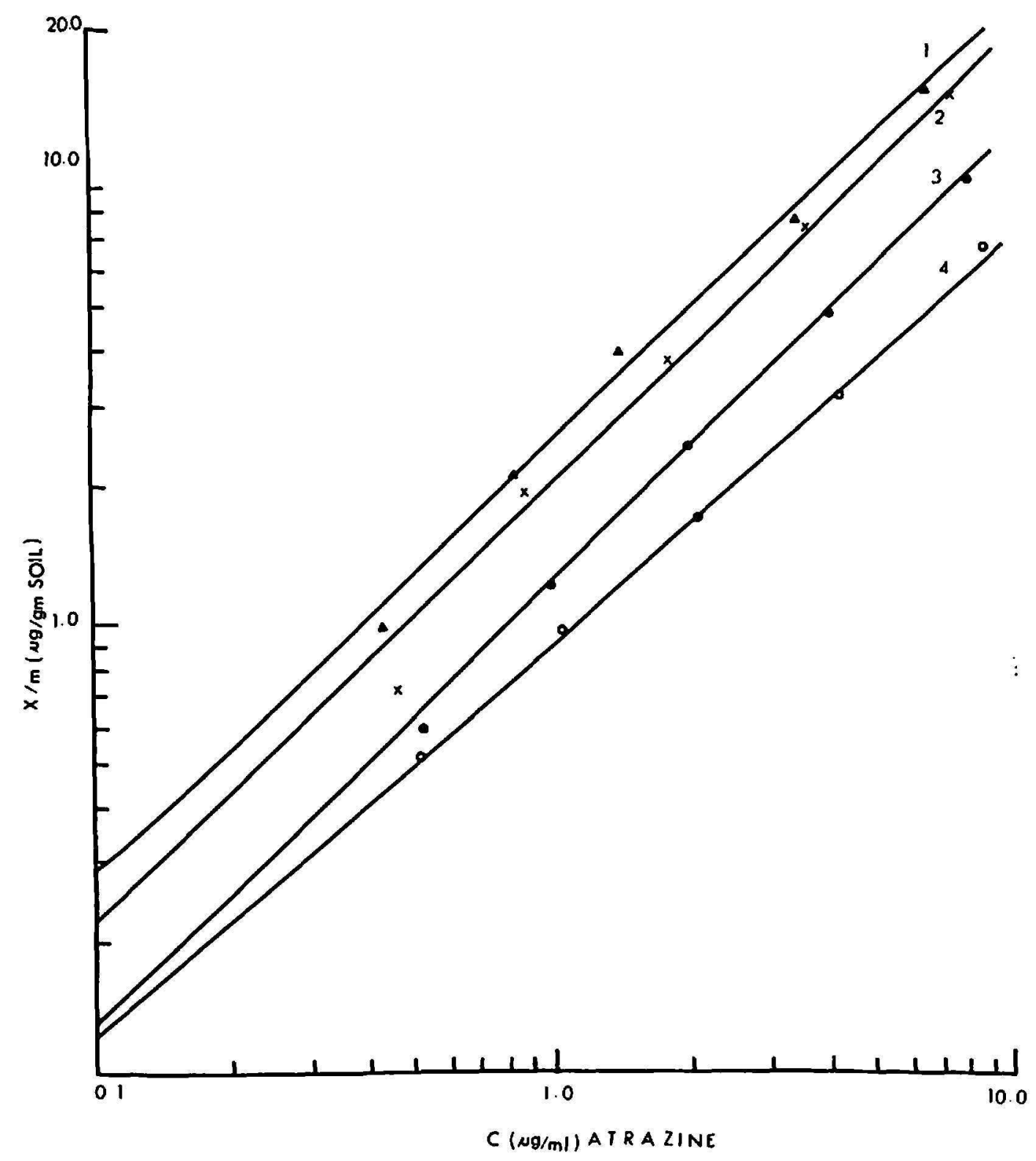

Fig. 1.-Freundlich adsorption isotherm for Atrazine and four soils. From top to bottom: A, Fortuıa silty clay loam; 2, Coloso clay loam; 3, Colo clay; and 4, Aguirre clay loam.

uracil (Terbacil) by 34 Puerto Rican soils was studied in the laboratory using $\mathrm{C}^{14}$-labeled herbicides. The various soils differed greatly in their capacity to adsorb Atrazine and Terbacil. The Caño Tiburones soil was found to be the most adsorptive for both herbicides; the Toa sandy loam 
and Talante sandy loam the least for Atrazine and Terbacil, respectively. Atrazine was consistently adsorbed to a greater degree than Terbacil. Adsorption of Atrazine was correlated positively with organic matter content, cation exchange capacity and magnesium and silt content but negatively with sand content. Adsorption of Terbacil was positively cor-

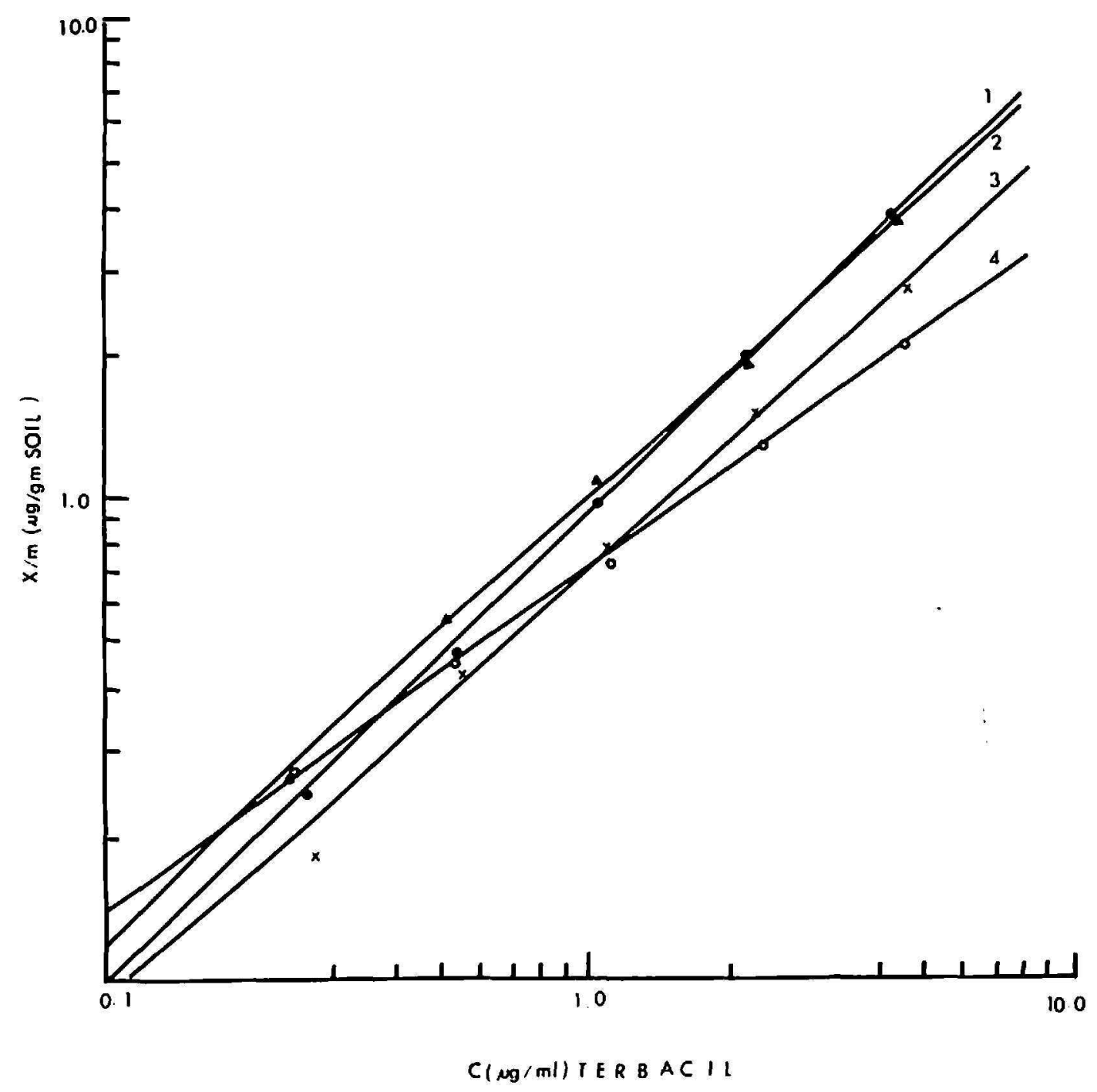

Fig. 2.-Freundlich adsorption isotherm for Terbacil and four soils. From top to bottom: 1, Coloso clay loam; 2, Fortuna silty clay loam; 3, Coto clay; and 4, Aguirre clay loam.

related with organic matter, cation exchange capacity, soil $\mathrm{pH}$, content of phosphorus, calcium, magnesium and clay but negatively with sand content of the soil.

Representative adsorption isotherms of Atrazine and Terbacil on several important island soils devoted to sugar'rane cultivation are also presented in this report. 


\section{RESUMEN}

Se estudió en el laboratorio, mediante el método del carbono $\left(\mathrm{C}^{14}\right)$, la diferencia en la capacidad adsortiva de 34 tipos de suelos de Puerto Rico respecto a Jos compuestos 2-cloro-4-(etilamino)-6-(isopropilamino)-s-triacin (Atrazine) y 3-butil-terciario-5-cloro-6-metiluracil (Terbacil). La diferencia en cuanto a dicha capacidad adsortiva fue grande entre varios de los suelos. El suelo Caño Tiburones demostró poseer la mayor capacidad para adsorber ambos yerbicidas, mientras que el Toa y el Talante, ambos margoarenosos, demostraron la menor capacidad para adsorber el Atrazine y el Terbacil, respectivamente. El Atrazine se adsorbió consistentemente en mayor grado que el Terbacil. Se demostró que existía una correlación positiva entre la adsorción del Atrazine y el contenido de materia orgánica, la capacidad para el intercambio de cationes y el contenido de magnesio y limo de los distintos suelos. Sin embargo, dicha correlatión fue negativa respecto al contenido de arena. En cuanto al Terbacil, también se encontró que existía una correlación positiva entre su adsorción y el contenido de materia orgánica, el intercambio de cationes, el $\mathrm{pH}$ y el contenido del fósforo, calcio, magnesio y arcilla de Jos suelos. Como en el caso del Atrazine, la correlación fue igualmente negativa respecto al contenido de arena.

En el estudio también se incluyen isotermos representativos de la adsorción del Atrazine y el Terbacil por varios de los mejores suelos que se dedican al cultivo de la caña de azúcar en Puerto Rico.

\section{LITERATURE CITED}

1. Hance, R. J., The speed of attainment of sorption equilibra in some systems involving herbicides, Heed Res. 5: 108-14, 1967.

2. Harris, C. I., Adsorption, movement, phytotoxicity of monuron and s-triazine herbicides in soil, Weeds 14: (6-10, 1966.

3. Harris, C. I., and Warren, G. F., Adsorption and desorption of herbicides by soil, Weeds 12: 120-26, 1964.

4. Hilton, H. W., and Yuen, Q. II., Adsorption of several pre-emergence herbicides by Hawaiian sugarcane soils, $J$. A yr. \& Fool Chem. 11:230-34, 1963.

5. Mee, J., Soil adsorption of terbacil, Hawaiian Sugar Experiment Station 1969 AnII. Rept. 75, 1970.

6. Liu, I. C., and Cibes-Viadé, H., Influence of soil properties on the phytotoxicity of Atrazine, Ametryne, Prometryue and Diuron in Puerto Rican soils, $J$. Agr. Univ. P.R. 52 (4): 2(99-80, 1968.

7. Liu, L. C., Cibes-Viadé, H., and Koo, F. K.S., Adsorption of ametryne and diuron by soils, Weerl Sci. 18: 470-74, 1970.

8. Mc(ilamery, M. D., and Slife, F. W., The adsorption and desorption of atrazine as affected by pII, temperature, and concentration, II eeds 14: 237-39, 1966.

9. Rhode, R. (., Belase(o), I. J., and Pease, 11. T., Determination of mobility and adsorption of agrichemicals on soils, $/$. Agr. d Food ('hem. 18: 524-28, 1970.

10. Talbert, R. L., and Fletchall, (1. II., The andsorption of some s-t riazines in soils, II eeds $13: 41.52,1965$. 